\title{
A new challenge for malaria control in Brazil: asymptomatic Plasmodium infection - A Review
}

\author{
José Rodrigues Coura/ ${ }^{+}$Martha Suárez-M utis, Simone Ladeia-Andrade
}

Departamento de Medicina Tropical, Instituto Oswaldo Cruz- Fiocruz, Av. Brasil 4365 21040-900, Rio de Janeiro, RJ, Brasil

The evolution of malaria in Brazil, its morbidity, the malaria control programs, and the new challenges for these programs in the light of the emergence of asymptomatic infection in the Amazon region of Brazil were reviewed.

At least six Brazilian research groups have demonstrated that asymptomatic infection by Plasmodium is an important impediment to malaria control, among mineral prospectors in Mato Grosso and riverside communities in Rondônia and, in our group, in the middle and upper reaches of the Negro river, in the state of Amazonas. Likewise, other researchers have studied the problem among indigenous communities in the Colombian, Peruvian, and Venezuelan parts of the Amazon basin, adjacent to Brazil.

The frequency of positive results from the polymerase chain reaction (PCR) among asymptomatic individuals has ranged from 20.4 to $49.5 \%$, and the presence of Plasmodium in the thick blood smears, from 4.2 to $38.5 \%$. Infection with Anopheles darlingi has also been demonstrated by xenodiagnosis among asymptomatic patients with positive $P C R$ results.

If a mean of $25 \%$ is taken for the asymptomatic infection caused by Plasmodium sp. in the Amazon region of Brazil, malaria control will be difficult to achieve in that region with the measures currently utilized for such control.

Key words: malaria - asymptomatic infection - control - Brazilian Amazon

Malaria is the most widespread and most serious parasitic disease in the world. Forty percent of the world's population ( 2.4 billion people) is exposed to the infection, especially people who live in tropical and subtropical countries. In these regions, between 300 and 500 million cases are diagnosed every year, causing 1.5 to 2.7 million deaths per year, mostly among African children (WHO 2002). In 2001, according to a review by Hay et al. (2004), the overall incidence of malaria in the areas at risk in the world was 396 million cases, of which more than $80 \%$ were on the African continent, leading to the death of 1,123,000 cases, mostly children (Hay et al. 2004).

In the Americas and in the Caribbean, $38 \%$ of the population (308 million people), in 21 countries, live in areas with malaria transmission, with a mean of 1.3 million cases per year. Thirty-six percent of these are in Brazil (OPS 1997, 1998, WHO 2002).

Since 1970, when just over 52,000 cases were recorded in Brazil, malaria has gradually been increasing in this country. In the 1990s, the number of cases surpassed 500,000 . In 1999, there were 610,000 notified cases of malaria in Brazil, and $99 \%$ of them were in the Amazon region (Ministério da Saúde 2003). Taking into account possible underreporting and cases of asymptomatic infection (Camargo et al. 1999, Alves et al. 2002, Suárez-Mutis et al. 2004, Ladeia-Andrade 2005), it may be considered that more than 600,000 cases are occurring in Brazil every year (personal estimation). The number of cases of malaria re-

Financial support: CNPq, Papes IV-Fiocruz +Corresponding author: coura@ioc.fiocruz.br Received 7 March 2006

Accepted 5 April 2006 ported decreased considerably in 2001 and 2002, perhaps because of the intensification of the control programs, but a progressive increase in malaria transmission became reestablished in Brazil from 2003 onwards. Figs 1 and 2 show the areas at risk (Fig. 1) and the number of malaria cases notified in Brazil from 1970 to 2005 (Fig. 2).

The course followed by malaria usually takes the form of a feverish acute systemic disease. The severity of the disease varies according to the parasite species (Plasmodium falciparum, $P$. vivax, $P$. malariae, and $P$. ovale; the last of these is not found in Brazil), the inoculum, the strain of the parasite, and the degree of previous immunity. Since the time of Hippocrates (460-377 BC), cases of infection of greater or lesser severity have been known. In 1900, Robert Koch first recognized cases of asymptomatic Plasmodium infection among patients in Papua New Guinea (Harrison 1978). This characteristic of malaria has been of concern for some time, particularly among investigators in Africa and Southeast Asia. More recently, it has become a concern in Brazil and other countries in Latin America and in the Caribbean, despite its lesser severity and the instability of its transmission in this region.

\section{Endemicity and stability of malaria}

The epidemiological classification for malaria was established by the World Health Organization in the 1950s (WHO 1950), on the basis of the spleen index among children aged 2 to 9 years and the intensity of transmission. Four levels were established:

Holoendemic malaria - When more than $75 \%$ of the children aged 2 to 9 years present a palpable spleen and the spleen index among adults is low. This occurs in areas with intense and continuous transmission.

Hyperendemic malaria - When 50 to $75 \%$ of the children have splenomegaly and the spleen index among 


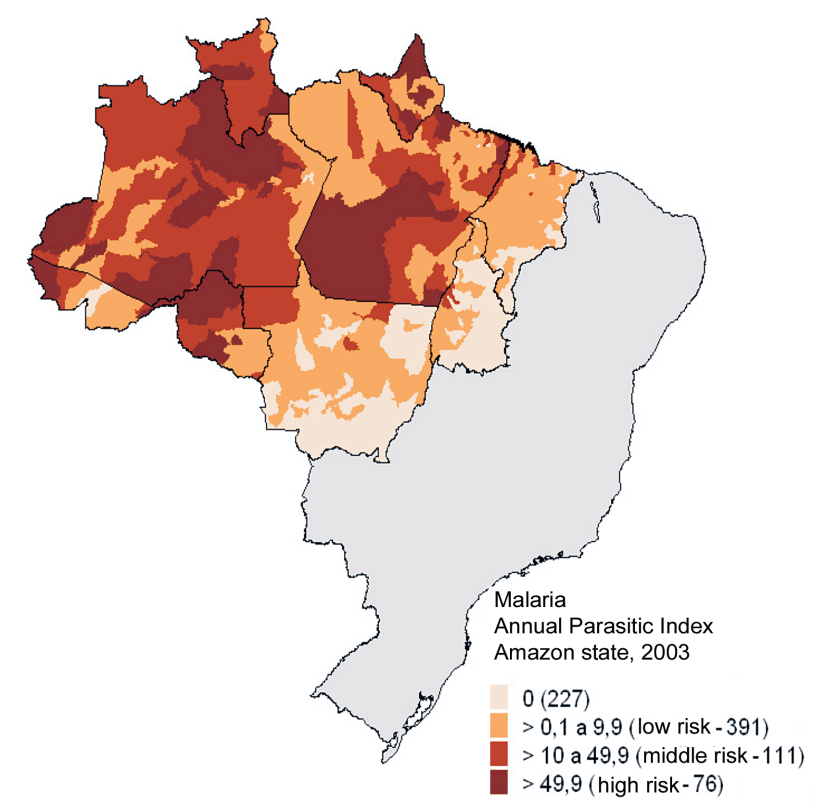

Fig. 1: malaria risk areas in Amazon states, Brazil, 2003. Source: Sivep-Malária. Ministry of Health.

adults is also high. This occurs in areas with intense but seasonal transmission.

Mesoendemic malaria - When 10 to $50 \%$ of the children have an enlarged spleen. This is characteristic of areas with wide variations in transmission.

Hypoendemic malaria - When less than $10 \%$ of the children have a palpable spleen. This occurs in areas with low and irregular transmission.
Although the WHO classification is valid for some areas, particularly Africa and Southeast Asia, where transmission takes place throughout the year and cases do not have immediate access to diagnosis and treatment, it does not apply well to the endemic areas of Latin America and the Caribbean, and particularly to Brazil, where transmission is usually seasonal (Ladeia-Andrade 2005, SuarezMutis 2005) and access to treatment or self-treatment is immediate, as occurs in the Amazon region of Brazil. In such cases, without constant stimulus, the immune response may become blocked at an early stage and splenomegaly may not be detectable.

MacDonald (1957) categorized the endemicity of malaria according to its stability, thus classifying areas as stable or unstable, albeit with wide epidemiological diversity between them. The most important stabilizing element in a population is the development of immunity. This author showed that the intensity and regularity of malaria transmission in a given area had an influence on the degree of immunity acquired. In areas of stable malaria, in which the transmission is intense and constant over the months and years, the population exposed develops high immunity. On the other hand, in areas of less intense and irregular transmission, varying from month to month and from year to year, malaria tends to be unstable. Thus, in areas of stable endemicity, the population is subjected to hundreds of infectious bites per man-year, but epidemics are rare because of the acquired immunity. In areas of unstable endemicity, on the other hand, individuals are subjected to few infectious bites but these areas suffer epidemics because of the population's low immunity (Carter $\&$ Mendis 2002).

Stable malaria results from the presence of one or more species of anophelines that frequently bite humans,

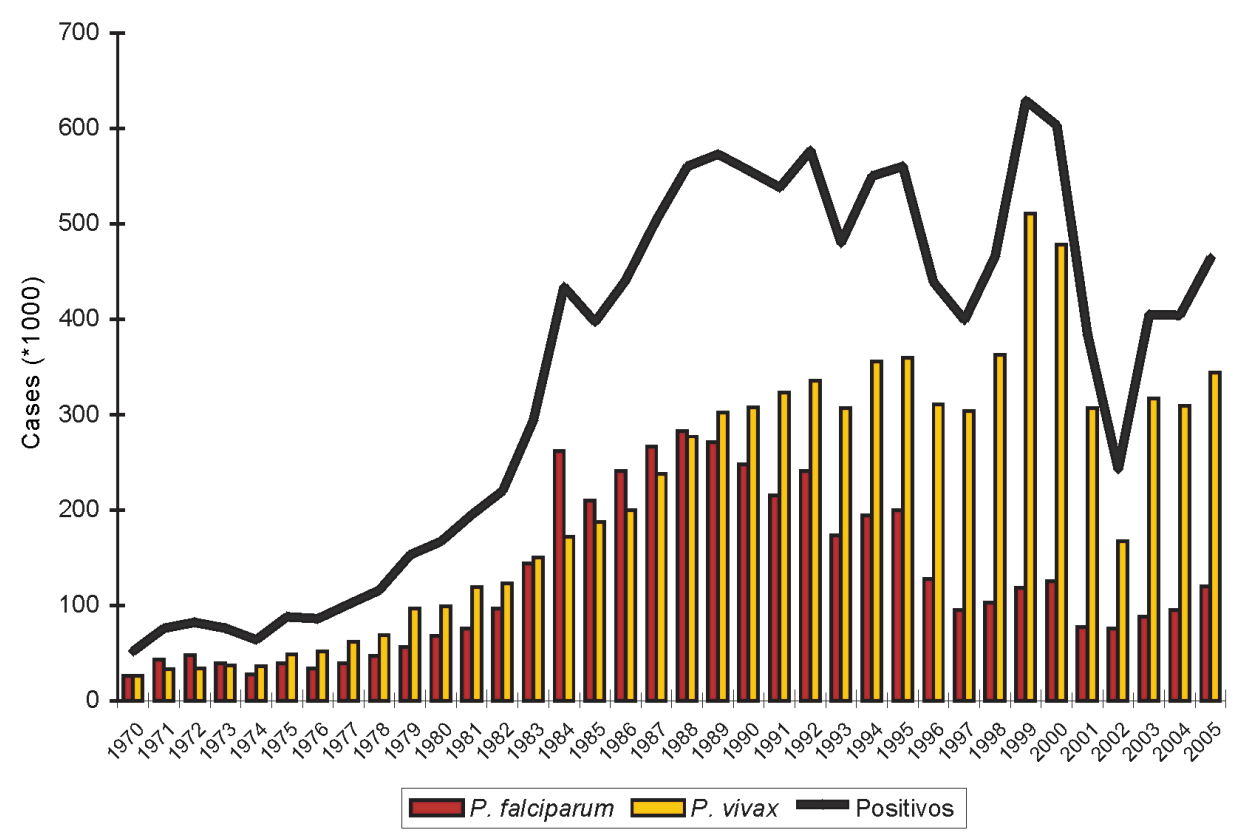

Fig. 2: malaria cases by parasitic species in Brazil from 1970 to 2005. Source: Sivep-Malária. Ministry of Health. Preliminary information. 
present high infection and anthropophilia rates, and have longevity favored by temperature and environmental conditions that enable multiplication in areas where control is absent or irregular. In contrast, unstable malaria occurs in areas where anopheline species present low infection rates and little anthropophilia, and they bite humans only irregularly or periodically, in accordance with the temperature, environmental and vector control conditions. In stable areas, malaria presents lower severity and is oligosymptomatic or asymptomatic among adults, but more severe in children. On the other hand, in unstable areas, malaria tends to occur in epidemic outbreaks that affect both adults and children, and these may be severe when the epidemics are caused by $P$. falciparum.

\section{Malarial morbidity in Brazil}

The first reports of autochthonous cases of malaria in Brazil date from the XVI century, arising as a natural consequence of the European colonization. By the end of the XIX century, malaria was present throughout Brazil (Martins Costa 1885, Barcelar 1963). By the start of the XX century, malaria was also present in all the Brazilian state capitals (Camargo 2003). Despite the estimates that 6 million cases of malaria were occurring in Brazil every year, i.e. affecting around 50\% of the country's population at that time, it was only at the end of the XIX century that the first great malaria epidemic erupted in the Amazon region. This coincided with the arrival of waves of immigrants from Northeastern Brazil, fleeing from drought in that region to seek work in rubber extraction in the Amazon region. Also because of rubber, to bring out latex from Bolivia, the construction of the Madeira-Mamoré Railway begun at the end of the XIX century and beginning of the XX century, to connect Santo Antônio, which today is a suburb of Porto Velho, to Guajaramirim on the Mamoré river. During this undertaking, thousands of workers, of whom a large proportion came from the Caribbean, died of malaria in the second great epidemic, which was monitored by Oswaldo Cruz (1910) and Carlos Chagas (1913).

The third great malaria epidemic occurred in the 1930s, with the arrival of Anopheles gambiae in Brazil. This was brought from Dakar on French ships to Natal and spread out from there throughout Rio Grande do Norte and part of Ceará. Upon hearing of this, the director of the PanAmerican Sanitary Bureau, Fred Soper, sent the following telegram to the head of the Brazilian Department of Health: "Poor Brazil". In 1938, one-fifth of the population of Rio Grande do Norte was infected with malaria, and in some riverside communities 80 to $90 \%$ of the population became ill, with many deaths (Soper \& Wilson 1943, Deane 1988). The Jaguaribe valley, in Ceará, was overwhelmed by the disease, which killed approximately $10 \%$ of its whole population because of the lack of timely treatment (Camargo 2003). Acting on a request from the Brazilian government, the Rockfeller Foundation began a strong campaign directed by Fred Soper himself. With the aid of notable Brazilian figures such as Marcelino Candau, Leonidas and Maria Deane, and Joaquim Eduardo Alencar, among others, An. gambiae was eradicated from Brazil, and this was certified in 1940. This is the only example of the eradication of this vector in the world.
With the occupation of the rubber plantations in tropical Asia by the Japanese during the Second World War, and because of the possibility of a shortage of rubber for wartime operations, a new wave of immigrants from Northeastern Brazil was "invited" into the rubber reserves of the Amazon region. They formed the "Rubber Soldiers", so called when more combatants died on this front, as malaria victims, than on the warfront against nazism and fascism (Camargo 2003). All these were determining factors for maintaining malaria in that region.

With the creation of the National Department for Rural Endemic Diseases (DNERu) in 1956, under the direction of Dr Mario Pinotti, the Malaria Eradication Campaign (CEM) was created, among other campaigns, and was given great emphasis by the director. Over a period of little more than 20 years, the disease was brought under control in the Southern, Southeastern, and Northeastern regions, and in part of the Center-West region, thus becoming restricted to the Northwestern and Amazon regions. In 1970, only 52,469 cases were notified, or in other words, 114 times fewer cases than at the beginning of the century, among a population that was then 15 times greater. Even at the start of the 1940s, Brazil was recording 6 million malaria cases per year, i.e. $1 / 7$ of the population of Brazil (IBGE 1993).

DNERu gave rise to the Superintendency of Campaigns (Sucam), which in conjunction with the Special Public Health Service (Sesp) respectively formed the bodies for vector control (Sucam) and medical care and basic sanitation in the interior of Brazil (Sesp), with emphasis on the Northeastern and Amazon regions. In their wisdom, the Brazilian authorities decided to merge Sesp and Sucam, to create the National Health Foundation (Funasa), which was transferred to Indians Health Care with decentralization of public medical services to the municipal authorities. However, particularly in the Amazon region of Brazil, the municipalities do not have the technical competency to carry out such tasks (Marques et al. 1994, Loiola et al. 2002).

Malarial morbidity in Brazil has been undergoing significance variations. With the appearance of resistance of $P$. falciparum to chloroquine in the 1960 s, malarial morbidity increased, as did the $P$. falciparum to $P$. vivax ratio, which reached more than $50 \%$ between 1984 and 1988. In 1989 , this proportion started to decrease and dropped to less than $20 \%$ between 1999 and 2003, since when it has started to rise again (Fig. 2). This recent increase in $P$. falciparum in relation to $P$. vivax has led to a consequent increase in morbidity due to the disease. On the other hand, because of the increase in malaria transmission, reduction in vector control and decline in medical care provided by the municipalities, there has been a trend towards increasing morbidity due to the disease, caused by the "infection pressure" itself.

The extent of the malarial morbidity is a function of the host's immunity, the strain of the parasite circulating in the locality, the resistance of the strain to treatment, the degree of instability of the area, the type and frequency of the vector control, and how early the medical care and treatment is provided by the health services. 


\section{Chronicity and asymptomatic infection}

As already mentioned at the start of this review, Robert Koch was the first to describe the presence of asymptomatic malaria infection, when studying patients in Papua New Guinea in 1900 (Harrison 1978). Since then, this phenomenon has intrigued scientists and, despite large numbers of studies conducted, basically in Africa and Southeast Asia, many questions remain to be answered. The greatest accumulation of information about symptomless infection is due to $P$. falciparum, although reports of asymptomatic infection due to $P$. vivax is also increasing.

In hyperendemic and holoendemic malaria areas, in which people suffer frequent infective bites, progressive acquisition of immunity is observed, thus leading to decreased number of malarial attacks with increasing age (Rogier \& Trape 1993). Thus, in these areas, the greatest number of malaria cases and the most severe cases occur among children aged between 6 months and 2 years, who have infections that progress with high parasitemia, morbidity, and mortality. Clinical immunity starts to appear with increasing age, at between 1 and 4 years or between 5 and 9 years, depending on the level of endemicity in the locality (Gupta \& Day 1994, Trape et al. 1994, Bloland et al. 1999, Soe-Soe et al. 2001). Children aged less than 6 months are often protected by their mothers' IgG (Edozien et al. 1962, Macgregor 1964a,b) and by the fetal hemoglobin (Pasvol et al. 1997). In these children, not only there are the presence of asymptomatic infection, but also there is reduced parasite density, thus suggesting the beginning of antiparasite immunity. From the age of 14 to 15 years, a marked diminution of parasitemia is observed, which sometimes reaches levels that are undetectable by the thick blood smear. However, using the most modern techniques of molecular biology, it has been demonstrated that the infection rate remains high until adulthood (Roper et al. 1996, Bottius et al. 1996). Most of the malarial infections in individuals living in these areas are asymptomatic. The children who are affected by the disease also have asymptomatic infections in most cases (Greenwood 1987, Trape et al. 1994, Owusu-Agyei et al. 2001).

The time taken for a child to acquire clinical immunity depends on the intensity of transmission and the genetic diversity of the parasite population in the locality (Snow et al. 1998). The maturity of the immune system also seems to be important, since children who have migrated from non-endemic areas to endemic areas develop protection more slowly than do adults (Baird et al. 1991). Several studies have documented the presence of large numbers of clones of the parasite co-infecting the same individual (Babiker et al. 1999). In holoendemic areas, there is an inverse relationship between multiple infection and clinical malaria (Contamin et al. 1996, A1-Yaman et al. 1997, Beck et al. 1997).

In the Americas, the reports of asymptomatic infection are relatively recent. In Brazil, Andrade et al. (1995) demonstrated that $70 \%$ of the cases among mineral prospectors in Mato Grosso were asymptomatic, and SuárezMutis et al. (2004) demonstrated that $20.4 \%$ of the cases among the population involved in extractive activities on the middle and upper reaches of the Negro river were as- ymptomatic. Roshanravan et al. (2003), studying populations in the Peruvian part of the Amazon basin, found a prevalence of $17.6 \%$, and Suárez-Mutis et al. (2000a,b) found a rate of $21.6 \%$ among indigenous populations in the Colombian part of the Amazon basin.

In a survey conducted in 1996 by Fontes (2001), in the Garimpo Satélite region of the municipality of Apiacás, in the northern part of Mato Grosso, a Plasmodium infection rate of $17.3 \%$ was found, i.e. 91 out of the 527 individuals examined using the thick blood film test. In $79.1 \%$ of them, there were low levels of parasitemia. Asymptomatic infection by Plasmodium was recorded in $41.8 \%$ (38/ 91) of the infected individuals (thus representing $7.2 \%$ of the total population). Of these asymptomatic patients, 14 were followed up without treatment for between 15 and 47 days (median of 24 days) and continued to be asymptomatic. In 2003, using the new molecular techniques of PCR on the samples collected by Fontes, Scopel detected nine cases of infection by Plasmodium spp. The prevalence of asymptomatic infection increased from $7.2 \%$ (the rate found in 1996) to $27.3 \%$. In the same population, Braga et al. (2002) observed a humoral response to the recombinant antigen MSP- $1_{19}$ of $P$. falciparum, and found higher levels of IgG1 antibodies among the asymptomatic individuals than among the symptomatic individuals living in the same area. This probably indicates that protection against becoming ill is starting to be acquired and is dependent on the balance between IgG isotypes (Braga 2002).

Alves et al. (2002), studying a riverside community on the Madeira river (Portochuelo) and six communities along the Ji-Paraná river, in Rondônia, found that PCR was 6 to 7 times more efficient than microscopy for detecting infections caused by Plasmodium. The prevalence of asymptomatic infections was 4 to 5 times greater than symptomatic infection, ranging from 6.4 to $31.7 \%$ in three different cross-sectional studies in Portochuelo and $64.8 \%$ along the Ji-Paraná river, with a mean of $49.5 \%$. The disease was more frequently found among younger individuals, while asymptomatic infection was found more among older groups. Asymptomatic infection was also more frequently found among people who had been living for a longer time in the area (means of 25.5 and 18 years in Portochuelo and Ji-Paraná, respectively).

A cross-sectional study carried out by Marcano et al. (2004) on the differences in malarial morbidity in two communities of the Yanomami, on the border of Brazil and Venezuela, showed a high frequency of asymptomatic cases on the Venezuelan side of the border, in relation to the Brazilian side (38.5 vs $4.9 \%$ ), a low frequency of serious cases in Venezuela in relation to Brazil (9.2 vs 36.5), high reactivity of the immune system in Venezuela, as measured by the frequency of splenomegaly, in relation to Brazil (72.4 vs $29.7 \%$ ), and a spleen index of $71.4 \%$ in Venezuela versus only $28.6 \%$ in Brazil. Likewise, high IgG antibody assays (77.4 vs $24.7 \%$ ) and mean IgM assays (120 vs 35) were found in Venezuela in relation to Brazil, respectively. This study showed that there was stability in the malaria transmission and consequent activation of the immune system, thus reducing the malarial morbidity in Venezuela in relation to Brazil and presenting asymptomatic case rates of, respectively, 38.5 and $4.9 \%$. 
Another recent study carried out in the Jaú National Park, in the middle reaches of the Negro river, in the state of Amazonas, by Ladeia-Andrade (2005), found that among 144 cases of malaria diagnosed by the presence of Plasmodium in the thick blood film test or by positive PCR results, $104(72.4 \%)$ were initially asymptomatic, $45(31.3 \%)$ continued to be asymptomatic for the next 30 days, and $36(25 \%)$ continued to be so for 150 days of follow-up. The spleen index for the children aged 2 to 9 years among the 540 individuals included in that study, which was conducted in three evaluations from November 2002 to July 2003, ranged from 9.2 to $13.6 \%$. This area can therefore be considered to be between hypoendemic and mesoendemic. The total ocurrence of malarial infection among the 540 individuals examined over that period was $14.4 \%$, among which two thirds of the cases were detected only by means of PCR. P. vivax was found in $74.7 \%$ of the infections, $P$. falciparum in $26.6 \%$, including mixed infection in $1.6 \%$, and $P$. malariae in $0.3 \%$. IgG antibodies for $P$. vivax and $P$. falciparum were detected by indirect immunofluorescence in 83.2 and $71.7 \%$, respectively, but the geometrical means of the assays were low (72.5 and 54.6), thus characterizing unstable transmission.

Other studies carried out in Brazil (Jones \& Neto 1971 Prata et al. 1988, Camargo et al. 1999, Andrade 2001a,b, Pithan et al. 2002, Scopel et al. 2005) and in other Latin American countries (Gonzalez 1997, Pérez 1998, Laserson et al. 1999, Suárez-Mutis et al. 2000a,b, Roper et al. 2000, Roshnavaran et al. 2003, Branch et al. 2005) were important for the global comprehension of the problem.

\section{Malaria control programs in Brazil}

The actions carried out by mankind to controlling malaria are as old as the disease. In the times of Hippocrates (460-377 BC), it was already being recommended that marshes should be "dried out" to reduce the impact of the "miasmas" that were said to cause malaria. In Brazil, at the beginning of the XX century, sanitary engineering activities to bury water collections on the peripheries of cities, and other strategies, were used with relative success in some places. The campaign against An. gambiae in Northeastern Brazil at the end of the 1930s and start of the 1940s is an excellent example of how, with determination, political commitment, and appropriate actions, it is possible to control serious public health problems. Over the last 40 years, a variety of initiatives have been put into action, with greater or lesser success. In 1965, Brazil adopted the malaria eradication campaign model (CEM) recommended by WHO, which is fundamentally based on vector control. Through the activities undertaken, together with deforestation and the urbanization of the populations of rural regions, a reduction in the transmission of Plasmodium was achieved in extensive areas of Brazil (Northeast, part of the Center-West, Southeast, and South). The same success was not obtained in the Amazon region, probably because the tropical rainforest offers ideal conditions for the reproduction of the mosquito vector, and because of the presence of highly exposed groups of humans, such as Indians, mineral prospectors, loggers, farmers in settlement projects, and people in- volved in extractive activities, among others. On the other hand, the high incidence of $P$. falciparum presenting resistance to antimalarial drugs for use in the field, and the lack of sanitary infrastructure in remote localities of a large proportion of the municipalities with malarial infections, facilitated the maintenance of the endemic disease.

In 1970, the Superintendency of Public Health Campaigns (Sucam) was created, but did not have the same operational capacity as CEM did, and which was also dedicated to control other endemic diseases. In 1980, Sucam started to use the strategy of epidemiological stratification, which allowed risk factors to be recognized and areas to be classified according to the epidemiological risk. Despite this, at the end of the 1980s the epidemiological picture for malaria began to worsen and the government sought new resources through international organizations, thus setting up the Malaria Control Program for the Amazon Basin (PCMAM). PCMAM had the objectives of reducing the occurrence of cases, promoting the development of Sucam and the state health departments, strengthening malaria control and giving specific attention to the indigenous communities. However, with a reorganization that Sucam underwent, the Foundation for Special Public Health Services (FSESP), which in turn was merged with Sucam to become the National Health Foundation (Funasa), and for other administrative reasons, PCMAM remained at a standstill for three years and only resumed operations in 1993.

In 1992, Ministerial Conference of Amsterdam took place, promoted by WHO, at which a new control strategy based on early diagnosis and timely and appropriate treatment for patients was established. Following this, the Integrated Malaria Control Program (PCIM) was created in Brazil. It contained some of the presuppositions of the PCMAM and maintained the principles of the Amsterdam Conference. The PCIM was also not implemented in all the municipalities in the country where malaria was a major public health problem. Between 1996 and 1997, Funasa drew up a new plan, called the Plan for Intensification of Malaria Control Actions, for implementation in high-risk areas within the legally defined Amazon region.

One important milepost in the control strategies for this endemic disease over the last few years has been the WHO initiative known as "roll back malaria" (RBM). The philosophical basis for this is that malaria is a disease that goes beyond the health sector and therefore intersectoral action is needed for combating it, through also strengthening local health services (López-Antuñano 1992, Passos \& Fialho 1998, Loiola et al. 2002).

The program currently in operation in Brazil is the National Program for Malaria Prevention and Control (PNCM). This has the objective of reducing the incidence of malaria, the severe forms of the disease and the mortality rate, and also to eliminate transmission within the urban areas of the state capitals and maintain the absence of transmission in localities where such transmission has already been prevented (Ministério da Saúde 2003). To achieve these objectives, the program has been divided into nine components that correspond to the intervention strategies. 
1. Support for structuring the local health services, thus seeking to improve the capacity of the municipal and state health systems for meeting the demand and adequately developing public health, surveillance and control actions that allow the morbidity-mortality due to malaria to be reduced.

2. Diagnosis and treatment, with the aims of enabling early detection of malaria cases, identification of the parasite species and administration of timely and appropriate treatment as quickly as possible, so as to prevent severe cases of the disease, avoid deaths and eliminate infection sources, thereby contributing towards reducing transmission and also epidemics.

3. Strengthening of health surveillance, through an information system that allows decision-making, and also a technical regulatory system that keeps the norms of the control program up to date, on the basis of epidemiological analysis.

4. Skills acquisition for human resources that enables there to be skilled personnel at all levels for implementing the malaria control actions, so as to attain the objectives of the PNCM. This strategy is very important and is also defined within RBM as "strengthening of local intelligence".

5. Health education, communication, and social mobilization (ESMS). This component is based on the fact that the better informed the population is, regarding the way in which malaria is transmitted, the determining factors, the clinical manifestations, the need for correct diagnosis, and the use of appropriate medications, the more actively it will participate in the control of the disease.

6. Selective vector control. Differing from other programs, the selective vector control within the PNCM seeks firstly to gain knowledge of the local entomology so that subsequently the most appropriate vector control methods for each situation can be utilized, according to entomological and epidemiological criteria.

7. Development of malaria research to give direction to the control measures. It has been proposed that the important points of such research would relate to evaluation of the distribution of antimalarial drug resistance among the parasites; the effectiveness and cost-benefit of rapid diagnosis tests; the efficacy of therapeutic regimens used at present; the beliefs, attitudes, and practices of the populations regarding the treatments and protection measures; the resistance of Anopheles sp. to the insecticides utilized; and the effectiveness of impregnated mosquito nets. Furthermore, various other studies might be needed to gain better knowledge of the disease in specific epidemiological contexts.

8. Monitoring of the PNCM. This component has the aim of analyzing the epidemiological behavior of the disease, at each of the government levels, through result and process indicators.

9. Political sustainability, which is fundamental for ensuring the financial support and intersectoral coordination for implementing the PNCM and also the continuity of the actions proposed (Ministério da Saúde 2003).
Successful malaria control experiences in areas of high transmission were reported by Suárez-Mutis et al. (2000b), Pithan et al. (2002), and others. These were both based on active detection of parasitemic individuals, by investigations systematically using the thick blood smears, on all residents in the localities at risk, weekly or monthly, and by providing appropriate treatment. Of course, this type of strategy requires a good structure for the local health systems, especially because these are very remote areas, with dispersed populations and well-define characteristics (Macauley 2005).

\section{A new challenge for malaria control in the Amazon region}

In addition to the nine strategic components of the malaria control program in Brazil mentioned above, which need to be really implemented in practice and sustainably maintained, a new challenge is growing in importance: asymptomatic Plasmodium infection as a source of continuation of malarial infection.

The high rates of asymptomatic infection due to Plasmodium that have been reported in Brazil and other South American countries that border Brazil in the Amazon region, on the one hand demonstrate the extent of the problem and on the other, the fragility of some of these data, because of the lack of a homogenous criterion for defining "asymptomatic infection". Some of these rates have only been based on the presence of Plasmodium and its DNA, as demonstrated by PCR at the time of the initial diagnosis, without taking into consideration the prior clinical manifestations and the use of drugs, patient follow-up and Plasmodium species. It is clear that a proportion of the patients may be in the incubation period, they are asymptomatic but in prepatent period with parasitemia, and may present clinical manifestations just a few days or weeks later. On the basis of personal experience and other authors' experiences, Ladeia-Andrade (pers. commun.) is presenting a proposal for criteria to define asymptomatic Plasmodium infection, with the aim of standardizing these criteria as the basis for a homogeneous definition. It is also important to consider whether the patient had any clinical manifestation a few days earlier and whether he has received any kind of treatment that may have reduced the parasitemia and suppressed the symptoms. On the other hand, some species of Plasmodium, such as P. vivax and $P$. malariae may present manifestations at a later stage.

The experimental demonstration by Alves et al. (2005) that An. darlingi, the most important vector in the Amazon region, may be infected by patients who only present positive PCR results for P. vivax, at a rate of $1.2 \%$, was important but needs to be expanded. This finding creates a new challenge for malaria control: a situation in which a human Plasmodium reservoir is maintained, with individuals who are not treated because they are not diagnosed, since they are asymptomatic and thick blood smears are not taken. On the other hand, the diagnosing of such cases becomes difficult because of the low level of parasitemia, therefore the blood films are usually negative. Furthermore the impossibility of applying the PCR test for epidemiological surveillance, because it is an expensive and laborious method is an additional problem. 
The following points for discussion and investigation urgently need to be implemented:

(a) definition of what the asymptomatic Plasmodium infection is, taking into consideration the length of observation, diagnostic method and parasite species;

(b) experimental verification of the proportion of asymptomatic patients with evident parasitemia, who might transmit malaria by means of vectors or blood transfusion;

(c) researching of alternative methods for parasite concentration that are reliable, fast and inexpensive, for diagnosing asymptomatic Plasmodium infection;

(d) evaluation of indirect diagnostic methods such as investigations of antigens, specific proteins and the parasite DNA itself, which would be fast and inexpensive, for application in epidemiological surveillance and possible treatment of asymptomatic infection;

(e) determination of the prevalence of asymptomatic infection by geographical area, which might justify periodic mass treatment, if this were the case, in certain populations;

(f) determination of the mechanisms through which asymptomatic individuals develop antimalarial immunity;

(g) identification of localities in which asymptomatic infection is frequent, in order to study the ecology, transmission dynamics and associated risk factors, which will be useful information for implementing more effective control strategies;

(h) adoption of more aggressive strategies within the control programs for detecting and managing asymptomatic individuals.

\section{ACKNOWLEDGEMENTS}

To Prof. Marcos Boulos for the critical analysis and suggestions for improving this review.

\section{REFERENCES}

Alves FP, Durlacher RR, Menezes MJ, Krieger H, Silva LHP, Camargo EP 2002. High prevalence of asymptomatic Plasmodium vivax and Plasmodium falciparum infections in native Amazonian populations. Am J Trop Med Hyg 66: 641-648.

Alves FP, Gil LHS, Marrelli MT, Ribolla PEM, Camargo EP, Silva LHP 2005. Asymptomatic carriers of Plasmodium spp. as infection source for malaria vector mosquitoes in the Brazilian Amazon. J Med Ent 42: 777-779.

Al-Yaman F, Genton B, Reeder JC, Anders RF, Smith T, Alpers MP 1997. Reduced risk of clinical malaria in children infected with multiple clones of Plasmodium falciparum in a highly endemic area: a prospective community study. Trans $R$ Soc Trop Med Hyg 91: 602-605.

Andrade ALSS, Martelli CMT, Oliveira RM, Arias JR, Zicker F, Pang L 1995. High prevalence of asymptomatic malaria in Gold Mining areas in Brazil. Clin Infec Dis 20: 475.

Andrade SL 2001a. Malária vivax assintomática com resolução espontânea em indígena Katukina de área endêmica do vale do alto rio Juruá, estado do Acre. Rev Soc Bras Med Trop 34(Supl. I): 347-348.

Andrade S, Tanja A 2001b. Malária falciparum assintomática com cura espontânea em gestante do bairro Várzea, periferia da cidade Cruzeiro do Sul, estado do Acre. Rev Soc Bras Med Trop 34(Supl. I): 346.

Babiker H, Abdel-Wahab A, Ahmed A, Suleiman S, RanfordCartwright L, Carter R, Walliker D 1999 Detection of very low level Plasmodium falciparum gametocytesw using reverse transcriptase PCR. Mol Bioch Parasitol 99: 143148.

Barcelar RC 1963. Brazil's contribution to tropical medicine and malaria. Proceedings of the Seventh International Congresses on Tropical Medicine and Malaria, Gráfica Olimpica Editora, Rio de Janeiro.

Baird JK, Jones TR, Danidirgo EW, Annis BA, Bans MJ, Basri H, Purnomo, Masbar S 1991. Age-dependent acquired protection against Plasmodium falciparum in people having two years exposure to hyperendemic malaria. Am J Trop Med Hyg 45: 65-76.

Beck HP, Felger I, Huber W 1997. Analysis of multiple Plasmodium falciparum infections in Tanzania children during the phase III trial of the malaria vaccine SPf66. J Infec Dis 175: 921-926.

Bloland PB, Boriga DA, Ruebush TK, McCormick JB, Roberts JM, Oloo AJ, Hawley W, Lal A, Nanlen B, Campbell CC 1999. Longitudinal cohort study of the epidemiology of malaria infections in an area of intense malaria transmission. II. Descriptive epidemiology of malaria infection and disease among children. Am J Trop Med Hyg 60: 641-648.

Bottius E, Guanzirolli A, Trape JF, Rogier C, Konate L, Druilhe $P$ 1996. Malaria: even more chronic in nature than in previously thought; evidence for subpatent parasitaemia detectable by the polymerase chain reaction. Trans $R$ Soc Trop Med Hyg 90: 15-19.

Braga EM, Barros RM, Reis TA, Fontes CJF, Morais CG, Martins MS, Kretti AU 2002. Association of the IgG response to Plasmodium falciparum merozoite protein (Cterminal $19 \mathrm{Kda}$ ) with clinical immunity to malaria in the Brazilian Amazon region. Am J Trop Med Hyg 66: 461-466.

Branch OL, Casapia WM, Gamboa DV, Hernandez JN, Alava FF, Roncal N, Alvarez E, Perez EJ, Gotuzzo E 2005. Clustered local transmission and asymptomatic Plasmodium flaciparum and Plasmodium vivax malaria infections in a recently emerged, hypoendemic Peruvian Amazon community. Malaria J 4: 27-42.

Camargo EP 2003. Malaria, maleita, paludismo. Ci Cult 55: 2632.

Camargo EP, Alves F, Silva LHP 1999. Symptomless Plasmodium vivax infections in native Amazonians. Lancet 353: 1415-1416.

Camargo LMA, Noronha E, Salcedo JMV, Dutra AP, Krieger H, Silva LHP, Camargo EP 1999. The epidemiology of malaria in Rondonia (Western Amazon Region, Brazil): study of a riverine population. Acta Trop 72: 1-11.

Carter R, Mendis 2002. Evolucionary and historic aspects of the burden of malaria. Clin Microbiol 15: 564-594.

Chagas C 1913. Notas sobre a epidemiologia do Amazonas. Brasil Méd 27: 450-456.

Contamin HT, Faunder T, Rogier C, Bonnefoy S, Konate L, Trape JF, Mercereau-Puijalon O 1996. Different genetic characteristcs of Plasmodium falciparum isolates collected 
during successice clinical malaria episodes in Senegalese children. Am J Trop Med Hyg 54: 632-643.

Cruz OG 1910. Madeira-Marmoré Railway Company. Considerações gerais sobre as condições sanitárias do Rio Madeira. Papelaria Americana, Rio de Janeiro. In Oswaldo Gonçalves Cruz, Opera Omina, Impressora Brasileira, Rio de Janeiro, 1972.

Deane LM 1988. Malaria studies and control in Brasil. Am J Trop Med Hyg 38: 223-230.

Edozien JC, Gilles HM, Udeozo IOK 1962. Adult and cordblood gamma-globulin and immunity to malaria in Nigerians. Lancet 2: 951-955.

Fontes CJF 2001. Epidemiologia da Malaria e Fatores Associados à Infecção Assintomática por Plasmodium em uma População de Garimpeiros da Amazonia Brasileira (Mato Grosso, 1996), PhD Thesis, Universidade Federal de Minas Gerais, Belo Horizonte.

Gonzalez JM, Olano V, Vergara J, Arévalo-Herrera M, Carrasquilla G, Herrera S, López JA 1997. Unstable, low level transmission of malaria on the Colombian Pacific Coast. Ann Trop Med Parasitol 91: 349-358.

Greenwood B 1987. Asymptomatic malaria infections - Do they matter? Parasitol Today 3: 206-214.

Gupta S, Day KP 1994. A theoretical framework for the immunoepidemiology of Plasmodium falciparum malaria. Parasite Immunol 16: 361-370.

Harrison G 1978. Mosquitoes, Malaria and Man: a History of the Hostilities since 1880, John Murray, London, p. 172174.

Hay SI, Guerra CA, Tatem AJ, Noor AM, Snow RW 2004. The global distribution and population at risk of malaria: past, present and future. Lancet Infec Dis 4: 327-336.

Hippocrates (English translation by WHS Jones) 1923. Air, Water and Places, Heineemann, London, New York.

IBGE 1993. www.ibge.gov.br

Jones SA, Neto JAF 1971. Symptoless Plasmodium vivax parasitaemias and malaria eradication in Santa Catarina state, Brazil. Rev Soc Bras Med Trop 5: 21-35.

Ladeia-Andrade S 2005. Aspectos Epidemiológicos da Malária no Parque Nacional do Jaú, Amazonas, Brasil, $\mathrm{PhD}$ Thesis Instituto Oswaldo Cruz-Fiocruz, Rio de Janeiro, 287 pp.

Laserson KF, Wypij D, Petralanda I, Spielman A, Maguire JH 1999. Diferential perpetuation of malaria species among Amazonian Yanomami Amerindians. Am J Trop Med Hyg 60: 767-773.

Loiola CCP, Mangabeira da Silva CJ, Tauil PL 2002. Controle da malária no Brasil: 1965-2001. Rev Panam Salud Publica 11: 235-244.

López-Antuñano F 1992. Epidemiology and control of malaria and other arthropod born diseases. Mem Inst Oswaldo Cruz 87(Suppl. III): 105-114.

Macauley C 2005. Aggressive active case detection: a malaria model strategy based on the Brazilian model. Social Sci Med 60: 563-573.

MacDonald G 1957. The Epidemiology and Control of Malaria, Oxford University Press, London.
Mac Gregor IA 1964a. The passive transfer of human malaria immunity. Am J Trop Med Hyg 13: 237-239.

Mac Gregor IA 1964b. Studies in the acquisition of immunity to Plasmodium falciparum infections in Africa. Trans $R$ Soc Trop Med Hyg 58: 80-92.

Marcano TJ, Morgado A, Tosta CE, Coura JR 2004. Crosssectional study defines diference in malaria morbidity in two Yanomami communities on Amazonian boundary between Brazil and Venezuela. Mem Inst Osw Cruz 99: 369376.

Marques AC, Gutierrez HC 1994. Combate à malária no Brasil : evolução, situação atual e perspectivas. Rev Soc Bras Med Trop 27 (Supl. III): 91-108.

Martins Costa DA 1885. A malaria e suas diversas modalidades (In Camargo 2003).

Ministério da Saúde 2003. Secretaria de Vigilância em Saúde, Programa Nacional de Prevenção e Controle da Malária PNCM, Brasília, DF.

OPS 1997. Situación de los Programas de Malaria en las Americas. Informe XLV, PAHO/WHO, Washington.

OPS 1998. Situación de la Salud en las Americas: indicadores básicos 1998. PAHO/WHO Informe XLVI, Washington.

Owusu-Agyei S, Koran KA, Baird K 2001. Incidence of symptomatic and asymptomatic Plasmodium falciparum infections following curative therapy in adult residents of Northern Ghana. Am J Trop Med Hy 65: 197-203

Passos A, Fialho R 1998. Malária: aspectos epidemiológicos e de controle. Rev Soc Bras Med Trop 31(Supl. II): 93-105.

Pasvol G, Weatherrall DJ, Wilson RJM 1997. Effects of foetal haemoglobin on susceptibility of red cells to Plasmodium falciparum. Nature 270: 171-173.

Perez S 1998. Anemia and malaria in a Yanomami Amerindian population from the Southern Venezuela Amazon. Am J Trop Med Hyg 59: 998-1001.

Pithan, OA, Santos J, Araújo D, Galdino P, Abreu H, Oliveira A 2002. Interruption of malaria transmission in semi-isolated indigenous areas: a proposal in light of the experience of PIACM in the Yanomami Health Distric. Proceedings of the second epidemiological exposition, Fortaleza, September.

Prata A, Urdaneta M, McGreevy PB, Tada MS 1988. Infrequency of asymptomatic malaria in an endemic area in Amazonas, Brazil. Rev Soc Bras Med Trop 21: 51-54.

Rogier C, Trape JF 1993. Malaria attacks in children exposed to high transmission: who is protected? Trans $R$ Soc Trop Med Hyg 87: 245-246.

Roper C, Elhassan IM, Hviid L, Giha H, Richardson W, Babiker H, Satti GM, Theander GT, Arnot DE 1996. Detection of very low level Plasmodium falciparum infections using the nested PCR and a reassessment of the epidemiology of unstable malaria in Sudan. Am J Trop Med Hyg 54: 325331.

Roper MH, Carrión TRS, Cava GCG, Andersen EM, Aramburú GJS, Calampa C, HightowerAW, Magill A 2000. The epidemiology of malaria in an epidemic area of the Peruvian Amazon. Am J Trop Med Hyg 62: 247-256.

Roshanravan B, Ari E, Gilman RH, Cabrera L, Lee E, Metclafe 
J, Calderon M, Lescano AG, Montenegro SH, Calampa C, Vinetz JM 2003. Endemic malaria in the Peruvian Amazon region of Iquitos. Am J Trop Med Hyg 69: 45-52.

Scopel KKG 2003. Infecção asintomática por Plasmodium sp. na Amazonia Brasileira: Detecção por PCR e Resposta de Anticorpos Anti-proteina 1 de Merozoito de Plasmodium falciparum, Thesis, Universidade Federal de Minas Gerais, Belo Horizonte.

Scopel KKG, Fontes CFJ, Ferreira MU, Braga E 2005. Plasmodium falciparum: IgG subclasse antibody response to merozoite surface protein-1 among Amazonian gold miners, in relation to infection status and disease expression. Exp Parasitol 109: 124-134.

Snow R, Gouws E, Omumbo J, Rapuoda B, Craig MH, Tanser FC, le Sueur D, Ouma J 1998. Models to predict the intensity of Plasmodium falciparum transmission: aplications to the burden of disease in Kenya. Trans $R$ Soc Trop Med Hyg 92: 601-606.

Soe-Soe, Shin-Saw-Aye, Htay-Aung, ThaniSwe, Roussilhon C, Pergnon JL, Druille P 2001. Premunition against Plasmodium falciparum. Trans $R$ Soc Trop Med Hyg 95: 81-84.

Soper FL, Wilson DB 1943. Anopheles gambiae in Brazil, 19301940, Rockfeller, New York (In Camargo 2002).

Suárez-Mutis MC, Bonilla MP, Blandón ME 2000a. Diagnosis of the health situation of the Yujup-Maku, a seminomadic indigenous group of the Colombian Amazonas. Abstracts 2 XVth International Congress for Tropical Medicine and Hygiene and Malaria, Cartagena, p. 192.

Suárez-Mutis MC, Bonilla MP, Blandón ME 2000b. Preven- tion and control of malaria among the Yujup-Maku, of la Libertad: an ethnic group on the brink of extinction. Abstracts $2 \mathrm{XV}$ th International Congress for Tropical Medicine and Hygiene and Malaria, Cartagena, p. 113.

Suárez-Mutis MC, Cuervo P, Fernandes O, Coura JR 2004. Evidência da presença de infecção assintomática por Plasmodium no médio rio Negro, Estado do Amazonas. Rev Soc Bras Med Trop 37(Supl. I): 268-269.

Suárez-Mutis MC, Cuervo P, Fernandes O, Coura JR 2005. Diferença na sazonalidade da infecção assintomática por Plasmodium em uma área endêmica de malária no medio rio Negro, Amazonas. Rev Soc Bras Med Trop 38 (Supl. I): 408 .

Trape JF, Rogier C, Konate L, Diagne N, Bouganali H, Canque B, Legros F, Badji A, Ndiaye G, Ndiaye P, Brahimi K, Faaye O, Druilhe P, Pereira da Silva L 1994. The Dielmo Project: a longitudinal study of natural malaria infection and the mechanisms of protective immunity in a community living in a holoendemic area of Senegal. Am J Trop Med Hyg 51: 123-137.

WHO-World Health Organization 1950. Expert Committee on Malaria, report on the Third Session. Technical Report Series no. 8 , Geneva.

WHO-World Health Organization 2002. The global malaria situation: current tools for prevention \& control. 55th. World Health Assembly. Global Fund to Fight AIDS, Tuberculosis \& Malaria, WHO document no. 55. Available at: http:// www.who.int/gb/ebwha/pdf_files/WHA55/ea55id6.pdf. Accessed 31 August 2004. 